\title{
Dipyrazolo[1,5-a:4',3'-c]pyridines - a new heterocyclic system accessed via multicomponent reaction
}

\author{
Wolfgang Holzer ${ }^{*}$, Gytè Vilkauskaitè ${ }^{1,2}$, Eglè Arbačiauskienė ${ }^{2}$ \\ and Algirdas Šačkus ${ }^{2}$
}

\section{Full Research Paper}

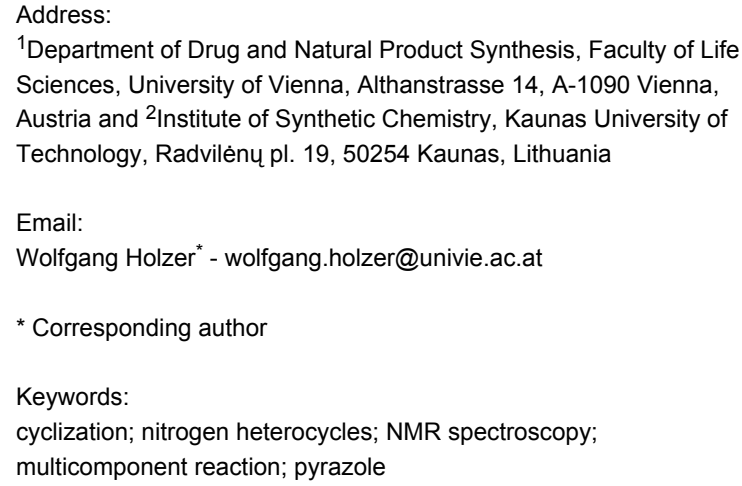

${ }^{1}$ Department of Drug and Natural Product Synthesis, Faculty of Life Sciences, University of Vienna, Althanstrasse 14, A-1090 Vienna, Austria and ${ }^{2}$ Institute of Synthetic Chemistry, Kaunas University of Technology, Radvilènu pl. 19, 50254 Kaunas, Lithuania

\begin{abstract}
The synthesis of dipyrazolo[1,5-a:4',3'-c]pyridines is described. Easily obtainable 5-alkynylpyrazole-4-carbaldehydes, $p$-toluenesulfonyl hydrazide, and an aldehyde or ketone containing an $\alpha$-hydrogen atom were reacted in a silver triflate catalyzed multicomponent reaction affording new tricyclic compounds with a dipyrazolo[1,5-a:4',3'-c]pyridine core. Detailed NMR spectroscopic investigations $\left({ }^{1} \mathrm{H},{ }^{13} \mathrm{C}\right.$ and $\left.{ }^{15} \mathrm{~N}\right)$ were undertaken with all obtained compounds.
\end{abstract}

\section{Introduction}

Condensed pyrazole scaffolds are important substructures of compounds with biological activity and can be found in some well-known drug molecules, such as, for example, Sildenafil (a pyrazolo[4,3- $d$ ]pyrimidine) [1,2], Allopurinol (a pyrazolo[3,4d]pyrimidin-4-one) [3], Zaleplon (a pyrazolo[1,5-a]pyrimidine) [4], and Zolazepam (a pyrazolo[3,4-e][1,4]diazepine derivative, used in veterinary medicine) [5]. Particularly pyrazolopyrimidines are a very frequently accessed class of compounds [6] with the particular importance of the pyrazolo[3,4- $d]$ pyrimidine core, which can closely mimic the purine system of adenosine and, thus, has been incorporated in various compounds impairing protein kinases and ATPases [7-9]. Moreover, a large variety of additional fused pyrazoles exhibit interesting biological activities, such as, pyrazolo[1,5-a]quinolones [10], pyrazolo[4,3-c] quinolones [11], pyrazolo[5,1-a]isoquinolines [12], and thieno[2,3-c]pyrazoles [13]. In view of these facts as well as due to our continuing interest in the exploration of useful but unused chemical space, which has become a paradigm of 


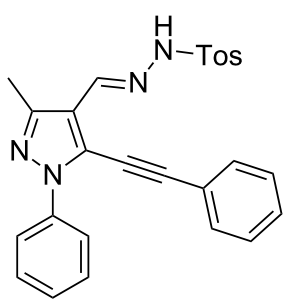

$2 a$

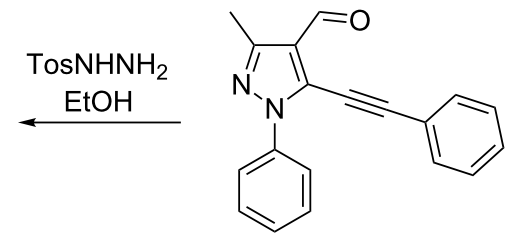

1a

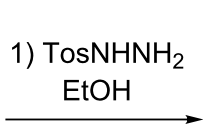

2) $\mathrm{AgOTf}$ $70{ }^{\circ} \mathrm{C}$

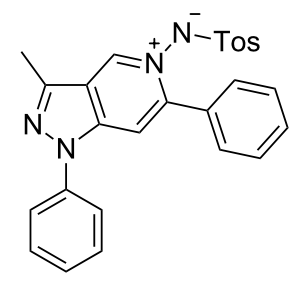

3a

Scheme 1: Intermediate reactions of pyrazole-4-carbaldehyde 1a.

contemporary medicinal chemistry [14], we have devoted some effort to the construction of novel condensed heterocyclic systems containing pyrazole substructures. Apart from a series of publications dealing with the construction of pyrazole analogues of xanthones and related systems [15-20] we recently described the synthesis of pyrano[4,3-c]pyrazol-4(1H)ones and -4(2H)-ones [21], 1,5-dihydro- resp. 2,5-dihydro$4 H$-pyrazolo[4,3-c]pyridin-4-ones [20], and pyrazolo[4,3-c]pyridines [22]. In continuation of these studies we herein present the synthesis and detailed NMR spectroscopic characterization of the new heterocyclic system dipyrazolo[1,5- $\left.a: 4^{\prime}, 3^{\prime}-c\right]$ pyridine. The access to the latter was achieved by a multicomponent reaction (MCR) starting from 5-alkynylpyrazole-4-carbaldehydes. Such MCRs, although being present since the early days of organic chemistry, nowadays attract an increasing interest because of their unmatched synthetic efficiency, which permits the construction of complex molecules in an elegant and sufficient manner [23-26].

\section{Results and Discussion}

\section{Chemistry}

The starting compounds for the construction of the title compounds are the 5-alkynylpyrazole-4-carbaldehydes 1 . Their synthesis from easily accessible 2-pyrazolin-5-ones through Vilsmeier formylation (with concomitant transformation of the oxygen into a chlorine substituent), followed by Sonogashira cross-coupling reaction of the obtained 5-chloropyrazole-4carbaldehydes with appropriate alkynes, has been described by us in a former publication [21]. Compounds 1 containing an alkyne function and a nucleophilic substituent in the ortho position of the pyrazole system are valuable precursors for the construction of corresponding annulated systems. In order to employ this arrangement of functionalities for the latter purpose, we adapted the approach of $\mathrm{Wu}$ and co-workers, who described the synthesis of $H$-pyrazolo[5,1- $a$ ]isoquinolines by a one-pot tandem reaction of 2-alkynylbenzaldehydes, sulfonohydrazide, and ketones or aldehydes [27]. In our case, application of pyrazolecarbaldehydes 1 should enable access to the desired dipyrazolo[1,5- $\left.a: 4^{\prime}, 3^{\prime}-c\right]$ pyridines 5.
In order to test the reaction conditions, firstly each step of the multicomponent reaction was carried out separately. According to the strategy, pyrazole-4-carbaldehyde 1a was primarily condensed with $p$-toluenesulfonyl hydrazide affording hydrazide 2a in $97 \%$ yield (Scheme 1). Secondly, two steps of the applied strategy were performed at once: condensation of $\mathbf{1 a}$ with $p$-toluenesulfonyl hydrazide and subsequent 6-endo-dig cyclization [28] of intermediate $\mathbf{2 a}$ in the presence of silver triflate produced $p$-toluenesulfonylazamide $\mathbf{3 a}$ in $91 \%$ yield (Scheme 1). The reaction of intermediate $\mathbf{3 a}$ with $\mathrm{CH}$-acidic aldehydes or ketones in the presence of base would lead to various dipyrazolo[1,5-a:4',3'-c]pyridines 5.

Thus, after these results, we decided to explore the one-pot tandem reaction with various 5-alkynylpyrazole-4-carbaldehydes 1, p-toluenesulfonyl hydrazide and butyraldehyde (4a). As alkynyl functions, phenylethynyl (1a,b), 3-thienylethynyl $(\mathbf{1 c}, \mathbf{d})$ and hex-1-ynyl (1e,f) were employed; silver triflate was used as the catalyst and $\mathrm{K}_{3} \mathrm{PO}_{4}$ as a base, needed for the formation of the second pyrazole ring. In this way, the dipyrazolo[1,5- $\left.a: 4^{\prime}, 3^{\prime}-c\right]$ pyridines $\mathbf{5 a}-\mathbf{f}$ were achieved in yields of $44-83 \%$ (Table 1, entries 1-6). Replacement of butyraldehyde by propionaldehyde (4b) or 3-phenylpropanal (4c) afforded the corresponding tricyclic products $\mathbf{5 g}, \mathbf{5 h}$ and $\mathbf{5 i}$ in 59-73\% yield, respectively (Table 1, entries 7-9). Lastly, application of the cyclic ketones cyclopentanone (4d), cyclohexanone (4e) and 2-methylcyclohexanone (4f) as carbonyl components resulted in the formation of tetracycles $\mathbf{5} \mathbf{j}-\mathbf{l}$ in acceptable yields (Table 1, entries 10-12).

\section{NMR spectroscopic investigations}

The NMR spectroscopic data of all compounds described in this study are given in Supporting Information File 1. Unequivocal assignment of resonances was carried out by the combined application of various standard NMR spectroscopic techniques, such as ${ }^{1} \mathrm{H}$ coupled ${ }^{13} \mathrm{C}$ NMR spectra, APT, HMQC, gs-HSQC, gs-HMBC, COSY, TOCSY, NOESY and NOE-difference spectroscopy [29]. In some cases experiments with selective excitation of certain ${ }^{1} \mathrm{H}$ resonances were performed, such as long- 
Table 1: Multicomponent reaction of various 5-alkynyl-1-phenyl-1H-pyrazole-4-carbaldehydes 1 with $p$-toluenesulfonyl hydrazide and aldehydes or ketones 4 .

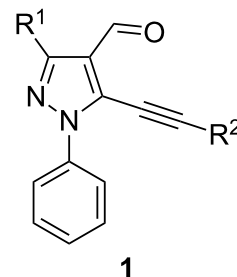

1) $\mathrm{Tos} \mathrm{NHNH}_{2}$, EtOH

2) $\mathrm{AgOTf}, 70{ }^{\circ} \mathrm{C}$

3) $\mathrm{R}^{3} \overbrace{\mathrm{R}^{4}}^{\mathrm{O}}, \mathrm{K}_{3} \mathrm{PO}_{4}$

4

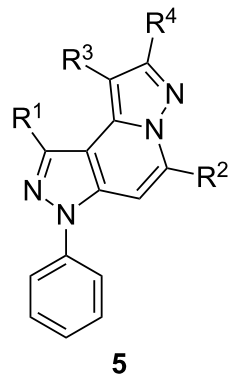

\section{Entry}

Compound 1

Compound 4

Product 5

Yield, \%

1<smiles>Cc1nn(-c2ccccc2)c(C#Cc2ccccc2)c1C=O</smiles>

$1 a$

2<smiles>O=Cc1cnn(-c2ccccc2)c1C#Cc1ccccc1</smiles>

$1 b$

3<smiles>Cc1nn(-c2ccccc2)c(C#Cc2ccsc2)c1C=O</smiles>

4<smiles>O=Cc1cnn(-c2ccccc2)c1C#Cc1ccsc1</smiles>

1d<smiles>CCCC=O</smiles><smiles>CCC[C+]C=O</smiles><smiles>CCCC=O</smiles><smiles>CCCC=O</smiles><smiles>CCc1cnn2c1-c1c(C)nn(-c3ccccc3)c1CC(c1ccccc1)=C2C</smiles>

47

73

73<smiles>[173I]Cc1cnn2c(-c3ccccc3)cc3c(cnn3-c3ccccc3)c12</smiles>

$5 b$<smiles>CCc1cnn2c(-c3ccsc3)cc3c(c(C)nn3-c3ccccc3)c12</smiles>

$5 c$<smiles>CCc1cnn2c(-c3ccsc3)cc3c(cnn3-c3ccccc3)c12</smiles>

5d 
Table 1: Multicomponent reaction of various 5-alkynyl-1-phenyl-1H-pyrazole-4-carbaldehydes 1 with $p$-toluenesulfonyl hydrazide and aldehydes or ketones 4. (continued)

5<smiles>CCCCC#Cc1c(C=O)c(C)nn1-c1ccccc1</smiles>

$1 e$

6<smiles>CCCCC#Cc1c(C=O)cnn1-c1ccccc1</smiles>

$1 f$

7<smiles>Cc1nn(-c2ccccc2)c(C#Cc2ccccc2)c1C=O</smiles>

1a

8<smiles>Cc1nn(-c2ccccc2)c(C#Cc2ccccc2)c1C=O</smiles>

1a

9<smiles>O=Cc1cnn(-c2ccccc2)c1C#Cc1ccccc1</smiles>

1b<smiles>CCCC=O</smiles>

$4 a$<smiles>CCCC=O</smiles><smiles>CCC=O</smiles><smiles>O=CCCc1ccccc1</smiles>

4c<smiles>O=CCCc1ccccc1</smiles>

$4 c$<smiles>CCCCc1cc2c(c(C)nn2-c2ccccc2)c2c(CC)cnn12</smiles>

$5 e$<smiles>CCCCc1cc2c(cnn2-c2ccccc2)c2c(CC)cnn12</smiles><smiles>Cc1nn(-c2ccccc2)c2cc(-c3ccccc3)n3ncc(C)c3c12</smiles>

$5 g$<smiles>Cc1nn(-c2ccccc2)c2cc(-c3ccccc3)n3ncc(Cc4ccccc4)c3c12</smiles>

$5 \mathrm{~h}$<smiles>c1ccc(Cc2cnn3c(-c4ccccc4)cc4c(cnn4-c4ccccc4)c23)cc1</smiles>

$5 i$ 
Table 1: Multicomponent reaction of various 5-alkynyl-1-phenyl-1 $\mathrm{H}$-pyrazole-4-carbaldehydes 1 with $p$-toluenesulfonyl hydrazide and aldehydes or ketones 4. (continued)

10<smiles>Cc1nn(-c2ccccc2)c(C#Cc2ccccc2)c1C=O</smiles>

1a

11<smiles>Cc1nn(-c2ccccc2)c(C#Cc2ccccc2)c1C=O</smiles>

1a

12<smiles>Cc1nn(-c2ccccc2)c(C#Cc2ccccc2)c1C=O</smiles>

1a<smiles>O=C1CCCC1</smiles><smiles>O=C1CCCCC1</smiles>

$4 \mathrm{e}$<smiles>CC1CCCCC1=O</smiles><smiles>Cc1nn(-c2ccccc2)c2cc(-c3ccccc3)n3nc4c(c3c12)CCC4</smiles>

$5 \mathbf{j}$<smiles>Cc1nn(-c2ccccc2)c2cc(-c3ccccc3)n3nc4c(c3c12)CCCC4</smiles>

$5 k$<smiles>Cc1nn(-c2ccccc2)c2cc(-c3ccccc3)n3nc4c(c3c12)CCCC4C</smiles>

51
46 range INEPT [30] and $2 \mathrm{D}(\delta, J)$ long-range INEPT [31], the latter experiments having been used for the unambiguous determination of long-range ${ }^{13} \mathrm{C},{ }^{1} \mathrm{H}$ coupling constants.

With compound 2a, the tosylhydrazone of starting aldehyde 1a, $(E)$-configuration at the $\mathrm{C}=\mathrm{N}$ double bond follows from an NOE between the iminyl-H (7.96 ppm) and $\mathrm{NH}(8.22 \mathrm{ppm})$ as well from the size of ${ }^{1} J(\mathrm{~N}=\mathrm{C}-\mathrm{H})(160.7 \mathrm{~Hz})$. In contrast, the (Z)-configuration and thus cis-position of the lone pair of the nitrogen and the coupled proton with respect to the $\mathrm{C}=\mathrm{N}$ double bond should result in a considerably larger ${ }^{1} J$-coupling due to lone-pair effects, which strongly influence such spin couplings $[32,33]$.

The target products $\mathbf{5 a}-\mathbf{l}$ show very consistent signal sets regarding the invariable part of the molecules. In the ${ }^{1} \mathrm{H}$ NMR spectra of congeners unsubstituted at position $1(\mathbf{5 b}, \mathbf{5 d}, \mathbf{5 f}, \mathbf{5 i})$ the signals due to $\mathrm{H}-1$ and $\mathrm{H}-4$ are split due to a small longrange coupling $\left({ }^{5} J(\mathrm{H}-1, \mathrm{H}-4) \sim 0.8 \mathrm{~Hz}\right)$. The signal of $\mathrm{H}-4$ is located within a relatively small range, namely between 6.85 and $7.20 \mathrm{ppm}$. Those compounds unsubstituted at position 8 show the H-8 signal at 7.75-7.91 ppm. Characteristic core signals in the ${ }^{13} \mathrm{C}$ NMR spectra are those of C-3a (134.8-136.7 ppm), C-4 (95.1-98.3 ppm), C-9 (5j: C-10a, 5k,l: C-11a) (105.6-114.6 ppm), C-9a (5j: C-10b, 5k,l: C-11b) (130.4-134.2) and C-9b (5j: C-10c, 5k,1: C-11c) (111.2-112.7 $\mathrm{ppm})$. The other carbon resonances (C-1, C-5, C-8) are influenced by the attached substituents to a somewhat larger extent. Also the ${ }^{15} \mathrm{~N}$ NMR spectra show a uniform pattern: the resonances of N-2 and N-3 are slightly influenced by the substituent at position 1 with the $1-\mathrm{H}$ derivatives having slightly larger chemical shifts than those of the corresponding 1-methyl congeners. The ${ }^{15} \mathrm{~N}$ chemical shifts of N-6 and N-7 are somewhat smaller with derivatives $\mathbf{5} \mathbf{j}-\mathbf{5 l}$ having a cycloaliphatic ring anellated to the concerning pyrazole ring. In Figure 1 the ${ }^{1} \mathrm{H}$, 


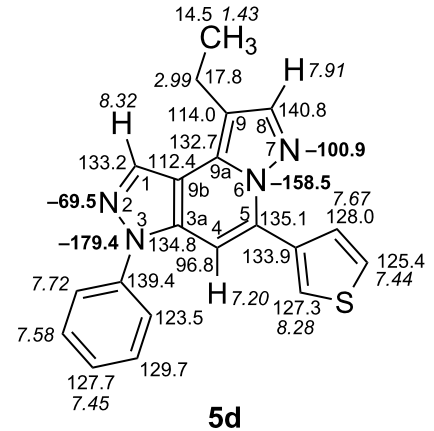

Figure 1: ${ }^{1} \mathrm{H}$ NMR (in italics), ${ }^{13} \mathrm{C}$ NMR and ${ }^{15} \mathrm{~N}$ NMR (in bold) chemical shifts of $\mathbf{5 d}$ in $\mathrm{CDCl}_{3}$ solution (with numbering of ring atoms).

${ }^{13} \mathrm{C}$ and ${ }^{15} \mathrm{~N}$ NMR chemical shifts are displayed for model compound $\mathbf{5 d}$, for which also the numbering of ring atoms is given.

The obtained NMR spectroscopic data are inasmuch valuable as the availability of reliable, unambiguously assigned chemical shift data is important as reference material for NMR prediction programs, such as CSEARCH/NMRPREDICT [34,35] or $\mathrm{ACD} / \mathrm{C}+\mathrm{H}$ predictor [36]. Such programs have become more and more popular in the past few years, particularly for the prediction of ${ }^{13} \mathrm{C}$ NMR chemical shifts. However, the quality of such predictions is highly dependent on the disposability of authentic reference data of related structures, a criterion which is frequently not fulfilled for rare or new condensed heterocyclic systems, such as those described here.

\section{Conclusion}

In conclusion, we present a simple and nonlaborious method to access dipyrazolo[1,5- $a: 4$ ', 3'-c]pyridines from easily obtainable 5-alkynyl-1-phenyl-1 $H$-pyrazole-4-carbaldehydes through a silver triflate catalyzed one-pot tandem reaction with $p$-toluenesulfonyl hydrazide and an appropriate aldehyde or ketone. Moreover, the novel heterocyclic system was investigated in great detail by extensive NMR spectroscopic investigations including also ${ }^{15} \mathrm{~N}$. Further studies to exploit the synthetic potential as well as the biological activities of the latter compounds are in progress and will be published elsewhere.

\section{Supporting Information}

\section{Supporting Information File 1}

Experimental details and characterization data. [http://www.beilstein-journals.org/bjoc/content/ supplementary/1860-5397-8-251-S1.pdf]

\section{Acknowledgements}

Grant financed by the Scholarship Council of the Scholarship Foundation of the Republic of Austria is gratefully acknowledged by Gytė Vilkauskaitè.

\section{References}

1. Kleemann, A.; Engel, J.; Kutscher, B.; Reichert, D. Pharmaceutical Substances, 3rd ed.; Georg Thieme Verlag: Stuttgart/New York, 1999; pp 1725-1727.

2. Boolell, M.; Gepi-Attee, S.; Gingell, J. C.; Allen, M. J. Br. J. Urol. 1996 , 78, 257-261. doi:10.1046/j.1464-410X.1996.10220.x

3. Pacher, P.; Nivorozhkin, A.; Szabó, C. Pharmacol. Rev. 2006, 58, 87-114. doi:10.1124/pr.58.1.6

4. Elie, R.; Ruther, E.; Farr, I.; Emilien, G.; Salinas, E. J. Clin. Psychiatry 1999, 60, 526-544. doi:10.4088/JCP.v60n0806

5. DeWald, H. A.; Lobbestael, S.; Butler, D. E. J. Med. Chem. 1977, 20 1562-1569. doi:10.1021/jm00222a005

6. Singh, S.; Sharma, P. K.; Dudhe, R.; Kumar, N. Pharma Sci. Monit. 2011, 2, 131-144.

7. Radi, M.; Dreassi, E.; Brullo, C.; Crespan, E.; Tintori, C.; Bernardo, V.; Valoti, M.; Zamperini, C.; Daigl, H.; Musumeci, F.; Carraro, F.; Naldini, A.; Filippi, I.; Maga, G.; Schenone, S.; Botta, M. J. Med. Chem. 2011, 54, 2610-2626. doi:10.1021/jm1012819

8. Honigberg, L. A.; Smith, A. M.; Sirisawad, M.; Verner, E.; Loury, D.; Chang, B.; Li, S.; Pan, Z.; Thamm, D. H.; Miller, R. A.; Buggy, J. J. Proc. Natl. Acad. Sci. U. S. A. 2010, 107, 1375-1380. doi:10.1073/pnas.1004594107

9. Evans, L. E.; Cheeseman, M. D.; Jones, K. Org. Lett. 2012, 14, 3546-3549. doi:10.1021/ol301561a

10. Barrett, D.; Sasaki, H.; Kinoshita, T.; Fujikawa, A.; Sakane, K. Tetrahedron 1996, 52, 8471-8488. doi:10.1016/0040-4020(96)00415-2

11. Mekheimer, R. A.; Ahmed, E. A.; Sadek, K. U. Tetrahedron 2012, 68 , 1637-1667. doi:10.1016/j.tet.2011.10.088

12. Chen, Z.; Wu, J. Org. Lett. 2010, 12, 4856-4859. doi:10.1021/ol101988q

13. Tonani, R.; Bindi, S.; Fancelli, D.; Pittala, V.; D’Anello, M. Heterobicyclic Pyrazole Derivatives as Kinase Inhibitors. U.S. Patent 20060160874 , July 20, 2006.

14. Marson, C. M. Chem. Soc. Rev. 2011, 40, 5514-5533. doi:10.1039/c1cs15119c

15. Eller, G. A.; Wimmer, V.; Haring, A. W.; Holzer, W. Synthesis 2006, 4219-4229. doi:10.1055/s-2006-950324

16. Eller, G. A.; Haring, A. W.; Datterl, B.; Zwettler, M.; Holzer, W. Heterocycles 2007, 71, 87-104. doi:10.3987/COM-06-10908

17. Eller, G. A.; Holzer, W. Molecules 2007, 12, 60-73. doi:10.3390/12010060

18. Eller, G. A.; Datterl, B.; Holzer, W. J. Heterocycl. Chem. 2007, 44, 1139-1143. doi:10.1002/jhet.5570440526

19. Eller, G. A.; Zhang, Q.; Habicht, D.; Datterl, B.; Holzer, W. Acta Chim. Slov. 2009, 56, 521-526.

20. Eller, G. A.; Habicht, D.; Holzer, D. Chem. Heterocycl. Compd. 2008, 44, 709-714. doi:10.1007/s10593-008-0106-5

21. Arbačiauskienè, E.; Vilkauskaitè, G.; Šačkus, A.; Holzer, W. Eur. J. Org. Chem. 2011, 1880-1890. doi:10.1002/ejoc.201001560

22. Vilkauskaitè, G.; Šačkus, A.; Holzer, W. Eur. J. Org. Chem. 2011, 5123-5133. doi:10.1002/ejoc.201100626

23. Isambert, N.; Lavilla, R. Chem.-Eur. J. 2008, 14, 8444-8454. doi:10.1002/chem.200800473 
24. Müller, T. J. J. Beilstein J. Org. Chem. 2011, 7, 960-961. doi:10.3762/bjoc.7.107

25. Zhu, J.; Bienaymé, H., Eds. Multicomponent Reactions; Wiley-VCH: Weinheim, Germany, 2005. doi:10.1002/3527605118

26. Dömling, A.; Ugi, I. Angew. Chem., Int. Ed. 2000, 39, 3168-3210. doi:10.1002/1521-3773(20000915)39:18<3168::AID-ANIE3168>3.0.CO $; 2-U$

27. Yu, X.; Ye, S.; Wu, J. Adv. Synth. Catal. 2010, 352, 2050-2056. doi:10.1002/adsc.201000176

28. Baldwin, J. E.; Thomas, R. C.; Kruse, L. I.; Silberman, L. J. Org. Chem. 1977, 42, 3846-3852. doi:10.1021/jo00444a011

29. Braun, S.; Kalinowski, H.-O.; Berger, S. 150 and More Basic NMR Experiments, 2nd ed.; Wiley-VCH: Weinheim, New York, 1998.

30. Bax, A. J. Magn. Reson. 1984, 57, 314-318.

31. Jippo, T.; Kamo, O.; Nagayama, N. J. Magn. Reson. 1986, 66, 344-348.

32. Gil, V. M. S.; von Philipsborn, W. Magn. Reson. Chem. 1989, 27, 409-430. doi:10.1002/mrc.1260270502

33. Heinisch, G.; Holzer, W. Monatsh. Chem. 1990, 121, 837-846. doi:10.1007/BF00808377

34. Kalchhauser, H.; Robien, W. J. Chem. Inf. Comput. Sci. 1985, 25, 103-108. doi:10.1021/ci00046a010

35. NMR Predict, 4.7; Modgraph Consultants, Ltd.: Herts, UK, 2010, http://www.modgraph.co.uk/product_nmr.htm.

36. $A C D / C+H$ Predictors and DB, 10.04; Advanced Chemistry Development, Inc.: Toronto, ON, Canada, 2006, http://www.acdlabs.com

\section{License and Terms}

This is an Open Access article under the terms of the Creative Commons Attribution License (http://creativecommons.org/licenses/by/2.0), which permits unrestricted use, distribution, and reproduction in any medium, provided the original work is properly cited.

The license is subject to the Beilstein Journal of Organic Chemistry terms and conditions:

(http://www.beilstein-journals.org/bjoc)

The definitive version of this article is the electronic one which can be found at: doi:10.3762/bjoc. 8.251 